\title{
Trends of Students' Participation in Science and Technology Bachelor Degree Programmes in Public Universities, Kenya
}

\author{
Bernard Wasilwa Wanyama $^{1, *}$, Daniel N. Sifuna ${ }^{1} \&$ Maurice I. Makatiani ${ }^{1}$ \\ ${ }^{1}$ Department of Educational Foundations, Kenyatta University, Nairobi, Kenya \\ *Corresponding Author: Department of Educational Foundations, Kenyatta University, \\ Nairobi, Kenya. E-mail: wanyama.bernard@ku.ac.ke
}

Received: December 7, 2020 Accepted: February 3, 2021 Published: March 20, 2021

doi:10.5296/ije.v13i1.18480 URL: https://doi.org/10.5296/ije.v13i1.18480

\begin{abstract}
Despite the government commitment to the implementation of admission policies targeting increasing the proportion of all students studying science-related programmes at Bachelors' level, only $29 \%$ of students were studying a course in Science and Technology by the year 2016. Such scenario implies that the country is seriously lagging behind in the realization of Kenya Education Sector Support Programme (KESSP I) participation target of $50 \%$. The purpose of this study was to explore the gaps which existed in the stated government policies designed to guide admission to science and technology bachelor's degree programmes and their actual practice during implementation. The study employed descriptive survey design and purposive sampling technique to select three Public Universities, 12 HoDs, 24 lecturers, and three Academic Registrars. Documentary analysis and interview schedules were utilized to collect data. Qualitative data was analyzed thematically and reported in form of tables, quotations and narrations while quantitative data was analyzed by use of frequencies, percentages, means, pie charts and bar graphs. It was established that enrolment stood at $41 \%$, graduation at $23 \%$ and Universities had prioritized $55.2 \%$ of their programmes in the same area. The study concludes that Universities should balance enrolment in science and technology and non-sciences and programmes have to be clearly aligned to the developmental needs of the country.
\end{abstract}

Keywords: bachelor degree, participation, public university, science and technology programmes 


\section{Introduction}

Global development agenda greatly focuses on science and technology education as one of the prioritized sector components and, as such, students' participation in such programmes in Universities needs to match the expectations of the goals of the development agenda (Kirimi, 2015; Filippetti \& Savona, 2017). However, by 2015, the Organization for Economic Co-operation and Development (OECD) member countries had three times more Humanities and Social Science graduates than Science, Technology, Engineering and Mathematics (STEM) graduates. The trend further pointed to a skewed global STEM graduates pool where China and India had $40 \%$ and 35\% STEM graduates respectively in 2012 and it was projected that by 2030, Brazil, Russia, Indonesia, India, China and South Africa (BRIICS) countries will produce three- quarters of global STEM graduates (OECD, 2015).

The demand for science and technology graduates in the United States of America (USA) was expected to increase at a Compounded Annual Growth Rate (CAGR) of 1.8\% between the years 2008-2018. However, by 2014, the supply of domestic science and technology graduates was not sufficient to meet the demand (Federation of India Chambers of Commerce and Industry, 2014). In Latin America and Caribbean countries, the average percentage of students graduating with science-related disciplines out of total graduates in 2013 was $11.7 \%$ (Ferreyra et $a l, 2017)$.

The Africa Union (AU) recently crafted the continents' most ambitious and long-term development blueprint dubbed as Agenda 2063 which recognizes the role of higher education in achieving the objective of balanced teaching hard sciences in areas of agriculture, livestock, health sciences and engineering in order to develop new technology. The blueprint envisages that by 2063 , at least $70 \%$ of all high school graduates will go on to tertiary education, with $70 \%$ of them graduating in the sciences and technology programmes (AUC, 2014). However, the continent faces enormous challenges in implementing this agenda. For instance, in 2016, there were a paltry 55,601 engineers in Africa while the estimated ideal number was 4,364,667 (ACBF, 2016).

There is poor enforcement of policy targets for science and technology programmes by higher education institutions. For instance, Kwame Nkrumah University of Science and Technology (KNUST) and University of Mines and Technology (UMAT) are science-based institutions. But over the years, they have expanded the number of arts and humanities programmes offered (Sam-Amoah et al, 2016; Atuahene \& Owusu-Ansah, 2013). Furthermore, several new programmes have been developed with a lot of specialization. For example, Bachelor of Science (B.Sc.) in Agronomy and Bachelor of Science in Seed Science were split from Bachelor of Science in Crop Science, a practice which made the over specialized graduates lack versatility (Valeta et al, 2016).

In Kenya, the need to enroll many students in science and technology Bachelor degree programmes has been articulated by the government from time to time (Republic of Kenya, $1974 ; 1976 ; 1979 ; 1981 ; 2006$; UNESCO, 2010). Currently, there are 31chartered public Universities in Kenya, all offering Programmes in science and technology. But the challenge of imbalance between the number of students studying science and arts based courses still persists 
(Republic of Kenya, 2005; 2006). The government committed to the implementation of investment programmes outlined in the Kenya Education Sector Support Programme (KESSP) 2005-2010 where one of the targets was increasing the proportion of all students studying science-related courses to $50 \%$ with at least one third of those being women by the year 2010 (Republic of Kenya, 2006; UNESCO, 2010). The actual placement of government sponsored students to Universities is coordinated by Kenya Universities and Colleges Central Placement Services (KUCCPS) and the placement policy requires that programmes must be identified as a priority area by the government (KUCCPS, 2014). In 2016, science and technology clusters recorded a paltry of $29 \%$ enrolment. Most poorly represented clusters were Veterinary at $0.2 \%$, Manufacturing $0.5 \%$, Architecture $1.2 \%$ and Mathematics 3.3\%. Yet these are some of the programmes identified as priority area for training with the potential to catapult the country to greater heights of development (Republic of Kenya, 2007; World Bank, 2014; Too et al, 2018).

Consequently, Kenya failed to meet KESSP I science and technology participation target of 50 per cent (UNESCO, 2010). The purpose of this study was therefore to explore the gaps which existed in the stated government policies designed to guide admission to science and technology Bachelor degree programmes and their actual practice during their implementation. The objective of the study was to explore the trend of students' participation in Science and Technology Programmes at Bachelor Level in Public Universities in line with Government of Kenya admission policies.

\section{Research Question}

The study sought to answer the following question:

To what extent is the trend of students' participation in Science and Technology Programmes at Bachelor Level in Public Universities in line with Government of Kenya admission policies?

\section{Review of Related Literature}

This section covers review of related literature on status of participation in Science and Technology Programmes cascaded from a global viewpoint to regional level and then national level. Yingyi \& Liu (2017) conducted an intersectional study on entry and degree attainment in Science Technology Engineering and Mathematics (STEM) subjects in United States of America (USA) by sampling 9272 students of non- Hispanic whites, non-Hispanic blacks, Hispanics and Asians. The study revealed that women and racial minorities are more under-represented in physical STEM fields. It further revealed that racial disparities in completing STEM degrees are much larger than at the entry point, where blacks and Hispanics trail behind Asians and whites in persistence (Yingyi \& Liu, 2017). Bagde et al (2016) conducted an empirical review of the admission policy in 225 Indian Engineering Colleges and found out that the most disadvantaged castes participated in Engineering Programmes in smaller proportion than their population shares (Bagde et al, 2016). 
Koketso (2015) conducted a qualitative research on understanding the gender disparity in enrolment and graduation in post-secondary education in Botswana. The study revealed that female enrolment in engineering and technology stood at $20 \%$ and that male students were $60 \%$ more likely than female students to receive associates degree in STEM-related fields (Koketso, 2015). This study identified gaps of interest in studies conducted by Yingyi \& Liu, 2017; Bagde et al, 2016 and Koketso, 2015. The gap in the Yingyi \& Liu study was that although intersectional studies address marginalization both in feminist and antiracist policies, it narrowed too much on entry and degree attainment in STEM at the intersection of gender and race/ethnicity. The gap in Bagde et al, study was that it majorly focused on participation in Engineering programmes based on different castes. Another limitation was being too general by reviewing admission policy in 225 colleges which offered Engineering programmes in India while the study by Koketso (2015) equally focused on gender disparities in enrolment and graduation. In that regard, our study broadened the scope to explain participation in Science and Technology Programmes irrespective of gender, caste, ethnicity or race. Moreover, it carried out an in-depth study in only three Public Universities in Kenya and discovered more detailed information about government policies on admission into the stated programmes.

Garwe (2015) did a study on trends in students' enrolments in Agricultural Degree Programmes in Zimbabwe. The study utilized documentary evidence and structured questionnaire. Data was collected from 15 Universities, 250 students for a span of 6 years (2009-2014). The study found out that despite the increase in number and variety of agriculture-related programmes, the share of enrolments in those programmes, compared to overall enrolments, showed a downward trend (Garwe, 2015). Although agriculture was one of the subjects in STEM programmes, the study by Garwe narrowed too much on a single programme and the findings could not give a clear picture on the number and variety of STEM related programmes. Apart from agriculture programme, our study broadened the scope by also analyzing trends in students' enrolments in Manufacturing Engineering Programmes.

Mpehongwa (2014) conducted a documentary review on career choices of University students and their implications for Vision 2025 in Tanzania and found out that enrolment in sciences (Agriculture, Engineering, Medicines and Natural Sciences) had decreased to 23,922, representing 17.6\% while that of Arts and Humanities (Business and Management, Education, Law and Social Sciences) had increased to 111,445, representing 82\% between 2006-2011 (Mpehongwa, 2014). Another study in East Africa by Karimi (2015) on participation in academic programmes which sampled the websites of the national quality assurance agencies had similar findings, that there was over-subscription of students in the categories of Humanities and Commerce while Engineering, Architecture and Natural and Life Sciences, which were critical to the realization of the global development agenda, were not adequately being offered in East African Universities (Karimi, 2015).

One of the limitations in both studies by Mpehongwa (2014) and Karimi (2015) was collecting data from one source: documentary review for the case of Mpehongwa and websites in the case of Karimi. The gap was that data collected from one source could not be corroborated. But our study employed documentary analysis, self-administered questionnaires, open-ended interviews and structured observations to collect data from lecturers, students, Heads of 
Departments, and University administrators for possible corroboration. The second gap in the study by Karimi was the inclusion of Universities from Kenya, Uganda, Tanzania, Rwanda, Burundi and South Sudan which produced general information about students' participation in Science and Technology Programmes since these countries were experiencing varying levels of development. Nevertheless, our study focused on participation in Science and Technology Programmes in Public Universities in Kenya.

Sader \& Gabela (2017) carried out an inquiry on spatiality of widening participation in South Africa Higher Education Institutions (HEIs). The study revealed that out of 969,155 students enrolled in public HEIs, $18 \%$ of the starting number graduated and $48 \%$ had either dropped out or not completed their studies, which pointed out a very low retention rate (Sader \& Gabela, 2017). Misaro et al (2013) reviewed various literatures pertaining on the impact of massification on quality of higher education in Kenya. Their study was underpinned by Martin Trow's theory of massification of higher education and revealed an emerging trend of ever-increasing student enrolments (Misaro et al, 2013). Muema \& Lavery (2018) systematically reviewed literature with a quantitative synthesis of data on redefining quality in higher education in Kenya and found out a sharp rise in enrolment where the number doubled from 58,637 to 122,847 and further increased to 177,735 in 2009/2010. The second finding was that the number of graduating students increased by $93 \%$ in 2015 at 71,347 from a total of 36,847 students in 2012. The study further found out that 3408 programmes were offered at Bachelors, Masters, Doctoral and Postgraduate Diploma Levels, where most of the programmes were completely new (Muema \& Lavery, 2018).

Our study identified three gaps of interest in researches conducted by Sader \& Gabela (2017) in South Africa, Misaro et al (2013) in Kenya and Muema and Lavery (2018) in Kenya. First, the studies primarily looked at the numbers (massification of higher education) but failed to look at the question of enrolments, retention, and completions in specific programmes. The second gap was presenting consolidated data for enrolments and graduating numbers of Bachelors, Masters and $\mathrm{PhD}$ students. The third gap was presenting consolidated number of programmes offered at Bachelors, Masters, Doctoral and Postgraduate Diploma Levels. In light of the global development agenda, Africa Union's long-term development, Agenda 2063 which recognizes the role of balanced teaching of the hard sciences to develop new technology and Kenya's Vision 2030 which prioritizes training of science and technology, our study focused on enrolment, retention and completion in Science and Technology Programmes at Bachelors' Level. The study was guided by Eccle's (2002) Subject-Task-Value Theory to explain the importance attached to participating in these programmes.

\section{Methodology}

\subsection{Research Design}

This study adopted descriptive survey design method to explore the gaps that existed in the stated government policies designed to guide admission into science and technology bachelor degree programmes and the actual practice during implementation. Descriptive survey is a 
method of collecting information by interviewing or administering a questionnaire to a sample of individuals (Kombo \& Tromp, 2006). Cohen et al (2007) observed that data gathered from descriptive survey serve three main purposes, namely: describing the nature of existing conditions, comparing them to certain standards of life and determining the relationship between specific events. The design was found appropriate because it assisted the researchers to describe the trend of students' participation, compare KESSP I participation target of 50 per cent and the actual practice during 2013-2017 implementation periods.

\subsection{Location of the Study}

The study was carried out in three Public Chartered Universities in Kenya, namely; Technical University of Kenya (TUK), Moi University (MU) and Egerton University (EU) which were purposively sampled. Purposive sampling is intentional selection of informants based on their ability to elucidate a specific theme, concept or phenomenon and is often used when working with small samples after the researcher identifies diverse characteristics of the sample selection criteria prior to selecting the sample (Patton, 2002). The Universities were purposively sampled based on the set criteria. First, the University must have been operational during the time of the implementation of 2010 KESSP I admission policy which targeted enrolment of 50\% of all students in science and technology related courses (UNESCO, 2010). Secondly, the University had a strong foundation in science and technology demonstrated by high enrolment numbers in these programmes and offering a variety of them. The opinions of the lecturers was sought since they were the ones teaching, hence they understood participation trends. The HoDs were directly involved in the day- to- day running of the Departments while Academic Registrars were directly involved in admission of students. The summary of target population, sample size and sampling technique are presented in Table 1:

Table 1. Summary of Target Population, Sample Size and Sampling Technique

\begin{tabular}{lllll}
\hline Category & $\begin{array}{l}\text { Target } \\
\text { population }\end{array}$ & $\begin{array}{l}\text { Sample } \\
\text { size }\end{array}$ & $\%$ & $\begin{array}{l}\text { Sampling } \\
\text { technique }\end{array}$ \\
\hline Universities & 31 & 3 & 9.7 & Purposive \\
Manufacturing and Veterinary lecturers & 237 & 24 & 10.1 & Purposive \\
Academic Registrars in the sampled Universities & 31 & 3 & 9.7 & Purposive \\
Heads of Departments in sampled Universities & 107 & 12 & 11.2 & Purposive \\
Total & 375 & 39 & & \\
\hline
\end{tabular}

\subsection{Data Collection Instruments}

The study utilized two methods to collect data: open-ended interview and document analysis.

\subsubsection{Open-ended Interviews for Lecturers, Head of Departments and Academic Registrars}

Open-ended interviews yielded mainly crucial information on gaps in the number of students participating in Science and Technology Programmes and emerging trend like splintering of 


\section{Macrothink

the programmes, duplication and increasing the applied sciences programmes. Open-ended interviews were used to collect information from lecturers, HoDs and Academic Registrars because they are flexible, adaptive and offered credible- in-depth responses to compliment quantitative data already captured in the document analysis from a small group.

\subsubsection{Documentary Reviews}

Documentary analysis involves the study of exiting documents in order to illuminate deeper meanings which may be revealed by their coverage. Quantitative data was obtained from University records for academic programmes, students' enrolments and numbers graduating. Documentary analysis was used as a supplementary method of gathering information, especially from institutional records. Analysis of the records was utilized to explore the trend of students' participation in Science and Technology Programmes.

\subsection{Data Analysis}

This study mixed method analysis to explore the trend of student participation in Science and Technology Programmes.

\subsubsection{Analysis of Quantitative Data}

Quantitative data from student enrolment numbers, graduation numbers and number of programmes on offer were coded and analyzed using the Statistical Package for Social Sciences (SPSS) version 20. Comparative analysis was done focusing on KESSP science and technology participation target of 50\% and the actual practice during 2013-2017 implementation periods of the stated policy. The statistical data was transformed into frequencies, percentages, means, and bar graphs in order to address the research questions.

\subsubsection{Qualitative Data Analysis}

The qualitative data analysis focused on description and analysis of data from open- ended interview schedule from lecturers, HoDs and Academic Registrars'. Qualitative responses supplemented the findings in the quantitative data. The voices of the participants validated specific findings from the quantitative data.

\section{Results and Discussion}

A general trend in student enrolment into bachelor degree programmes at TUK was analyzed and the findings are presented in Figure 1: 


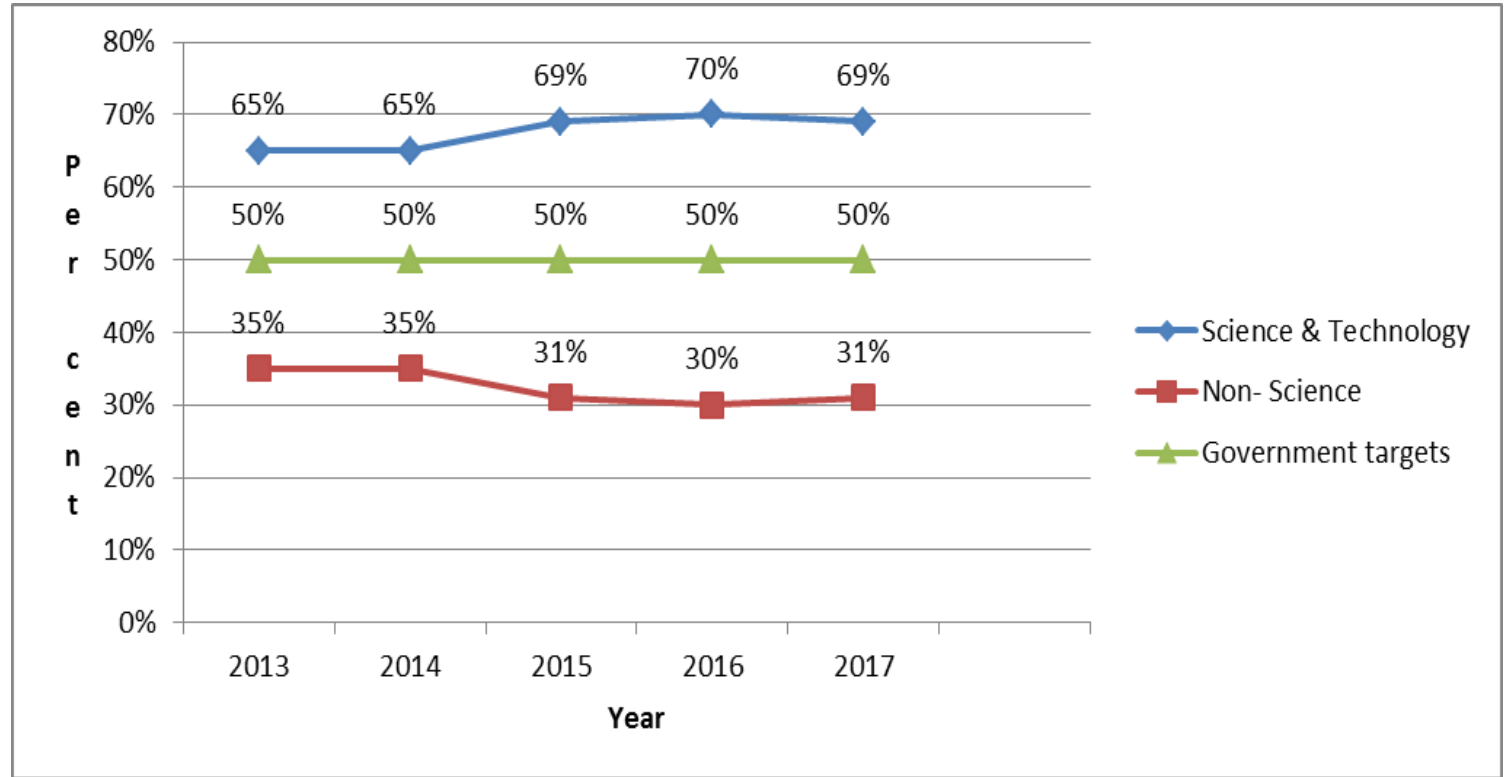

Figure 1. TUK General Trend in Students' Enrolment at Bachelor's Level 2013 and 2017

From Figure 1 above, enrolment into non-science programmes gradually dropped from 35\% in 2013 and 2014 to $30 \%$ in 2016 bringing the average to $32.4 \%$ while science and technology oscillated between 65\% and 70\% with the lowest witnessed in 2013 and 2014 at $65 \%$ and the highest of $70 \%$ in 2016 . The average enrolment into Science and Technology Programmes was therefore $67.6 \%$ superseding the government enrolment target of $50 \%$ by 17.6 percentage points.

A general trend in students' enrolment into Bachelor degree programmes at Moi University was analyzed and the findings are presented in Figure 2:

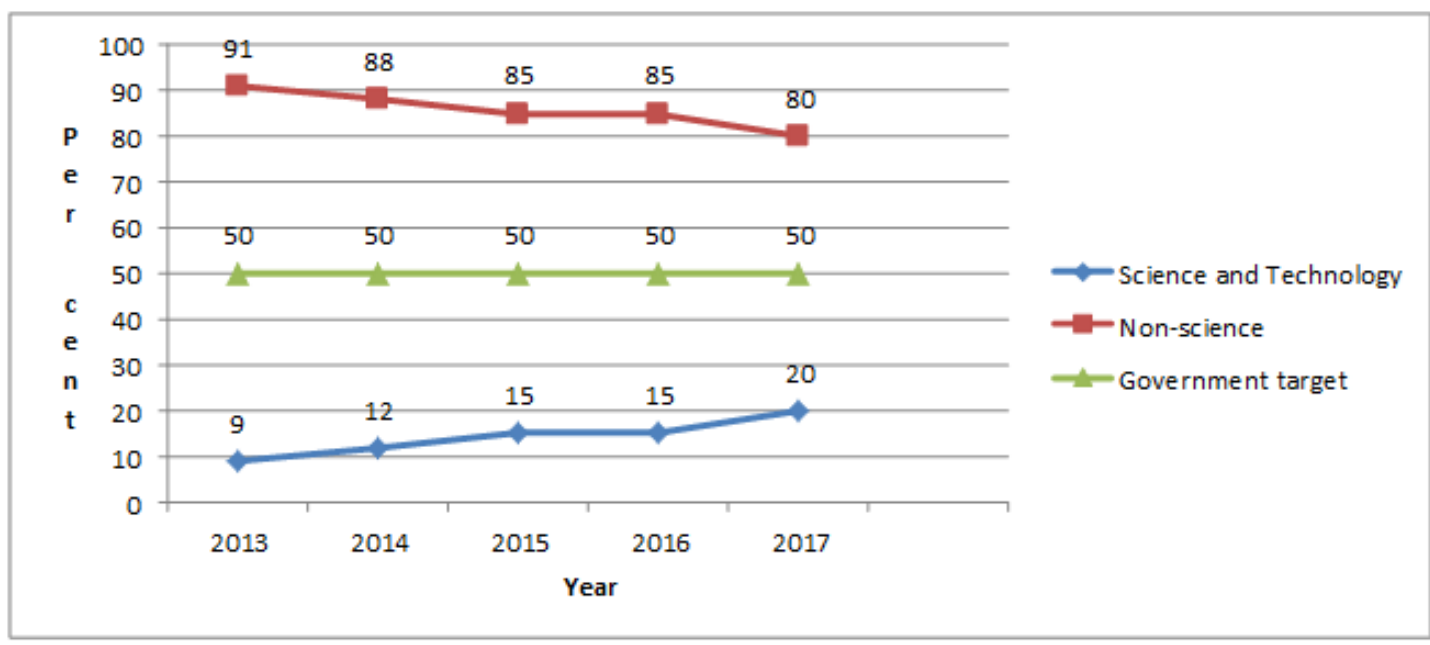

Figure 2. MU Government-Sponsored General Students' Enrolment Trend at Bachelors' Level between 2013 and 2017 
From Figure 2 above, enrolment into non-science programmes gradually dropped from 91\% in 2013 to $80 \%$ in 2017 making the average of $85.8 \%$ while enrolment into science and technology gradually increased from $9 \%$ in 2013 to $20 \%$ in 2017 . The average enrolment into Science and Technology Programmes was, therefore $14.2 \%$, missing the government target of $50 \%$ by a big margin of 35.8 percentage points. In this connection, one $\mathrm{HoD}$ explained:

By their nature, Science and Technology Programmes demand for significant investment to establish, maintain, and expand and the capital required is often prohibitively expensive. When Universities are confronted with significant pressure to expand admissions, there has been a tendency to push more students towards non-science programmes. (HoD response during open ended interview, November 2019)

Averagely, $41 \%$ of students enrolled into science programmes in the period reviewed, implying that the government target was missed by 9 percentage points. In conclusion, if this low enrolment trend is not addressed and appropriate evidence-based intervention measures implemented to reverse it, it is most likely that it will continue to the detriment of the Government of Kenya target. Thus, by the implication, Kenya would be failing to attain the industrialized status as envisaged in Kenya vision 2030. Additionally, this low enrolment meant that any likely benefits accruing from increased productivity and social economic development might be difficult to be realized. These findings were reinforced by Sam-Amoah et al (2016) and Atuahene \& Owusu-Ansah (2013) that University enrolment ratio of science and technology and arts and humanities was below the government projection.

The study collected data on enrolment in different clusters from University records and the findings from TUK are presented in Table 2:

Table 2. Enrolment Trends into Different Clusters at TUK for the Period 2013-2017

\begin{tabular}{|c|c|c|c|c|c|c|c|c|c|c|}
\hline \multirow{3}{*}{ Cluster } & \multicolumn{10}{|c|}{ Year } \\
\hline & \multicolumn{2}{|l|}{2013} & \multicolumn{2}{|l|}{2014} & \multicolumn{2}{|l|}{2015} & \multicolumn{2}{|l|}{2016} & \multicolumn{2}{|l|}{2017} \\
\hline & $\mathrm{F}$ & $\%$ & $\mathrm{~F}$ & $\%$ & $\mathrm{~F}$ & $\%$ & $\mathrm{~F}$ & $\%$ & $\mathrm{~F}$ & $\%$ \\
\hline $\begin{array}{l}\text { Engineering and } \\
\text { technology }\end{array}$ & 984 & 31.1 & 1087 & 29.4 & 915 & 27.3 & 1055 & 29.3 & 674 & 27.4 \\
\hline Architecture & 425 & 13.4 & 436 & 11.8 & 553 & 16.5 & 590 & 16.4 & 396 & 16.1 \\
\hline $\begin{array}{l}\text { Humanities and social } \\
\text { sciences }\end{array}$ & 566 & 18.0 & 638 & 17.3 & 503 & 15 & 489 & 13.6 & 405 & 16.6 \\
\hline $\begin{array}{l}\text { Life and physical } \\
\text { sciences }\end{array}$ & 403 & 12.7 & 645 & 17.4 & 580 & 17.3 & 653 & 18.2 & 423 & 17.2 \\
\hline Mathematics & 77 & 2.4 & 90 & 2.4 & 96 & 3 & 105 & 2.9 & 91 & 3.7 \\
\hline Business & 540 & 17.1 & 643 & 17.4 & 549 & 16.4 & 581 & 16.2 & 364 & 14.8 \\
\hline $\begin{array}{l}\text { Medical and health } \\
\text { sciences }\end{array}$ & 168 & 5.3 & 159 & 4.3 & 151 & 4.5 & 122 & 3.4 & 103 & 4.2 \\
\hline Total & 3,163 & 100 & 3,698 & 100 & 3,347 & 100 & 3,595 & 100 & 2,456 & 100 \\
\hline
\end{tabular}




\section{Macrothink}

Table 1 above indicates that engineering and technology cluster had the highest overall enrolment of $31.1 \%$, being highest in 2013 , and the least of $27.3 \%$ in 2015 bringing average enrolment to $29 \%$. Life and Physical Sciences followed with highest of $18.2 \%$ in 2016 and lowest of $12.7 \%$ in 2013 making the average to be $16.63 \%$. Business had the highest enrolment in 2014 at $17.4 \%$ and lowest of $14.8 \%$ in 2017 . Its average was $16.47 \%$. Humanities and Social Sciences had the highest of 18.0\% in 2013 and lowest in 2016 at $13.6 \%$. The average was $16 \%$ while Architecture had the highest enrolment of $16.5 \%$ in 2015 and lowest of $11.8 \%$ in 2014, making the average to be $14.76 \%$. The least enrolments were recorded in Mathematics which oscillated between 2.4\% in 2013 and 2014 and 3.7\% in 2017, making the average to be $2.82 \%$ followed by Medical and Health Sciences with $5.3 \%$ highest in 2013 and $3.4 \%$ lowest in 2016 , making the average to be $4.32 \%$.

This meant that although the general picture indicated highest enrolment into science and technology clusters, some other science and technology clusters like Medical and Health Sciences and Mathematics were largely underrepresented. Furthermore, some non- science clusters like Business and Humanities and Social Sciences are fairly well represented.

The findings for the enrolment trends into different clusters at MU are presented in Figure 3 below.

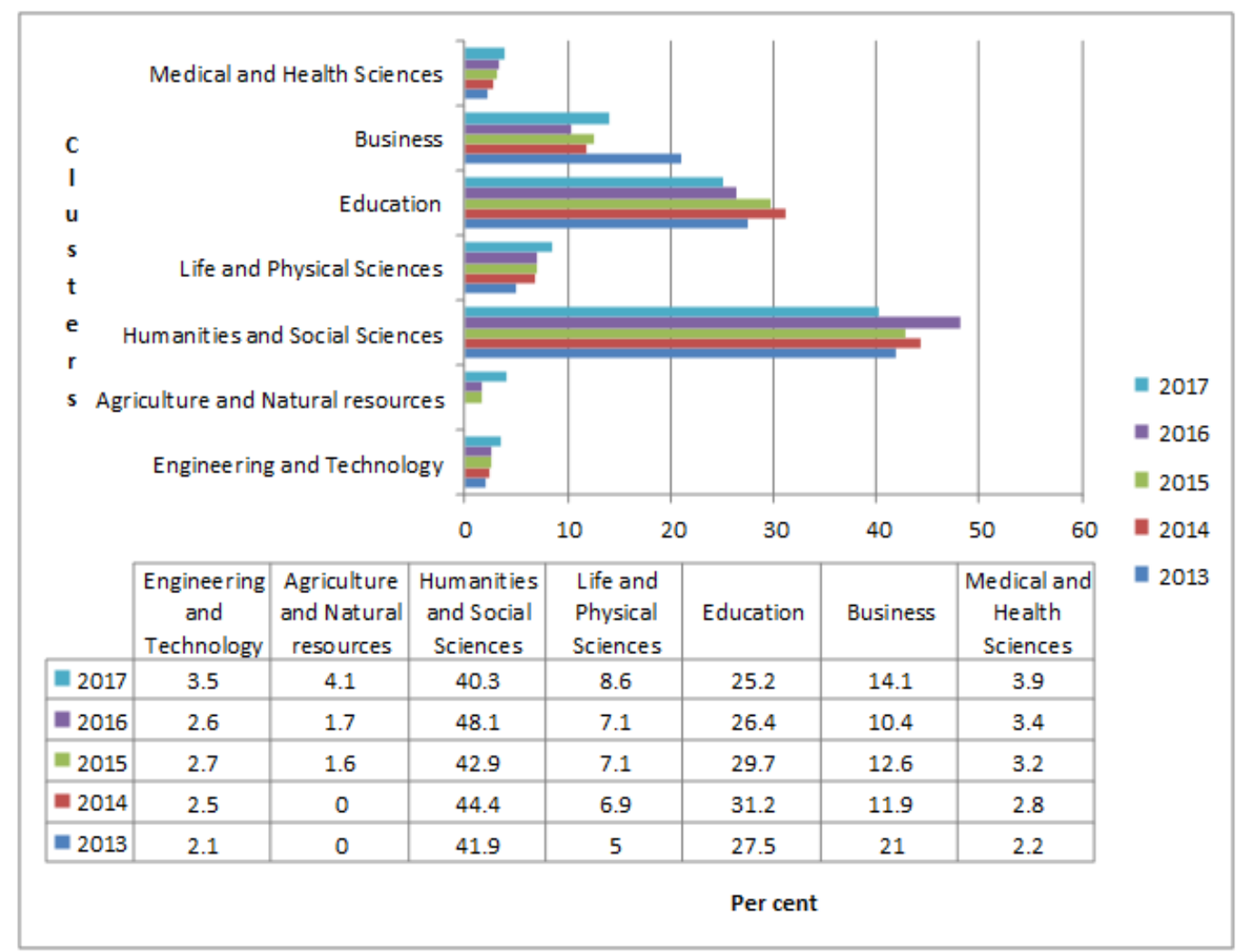

Figure 3. Enrolment Trend into Different Clusters at MU for the Period 2013-2017 


\section{Macrothink

Information in Figure 3 indicates that the lowest enrolment was in Agriculture and Natural Resources which recorded $0 \%$ in 2013 and 2014 respectively. It gradually increased from a paltry of $1.6 \%$ in 2015 to $4.1 \%$ in 2017 . Averagely, $1.46 \%$ enrolled into Agriculture and Natural Resources. The same low trend was recorded in Engineering and Technology which gradually increased from $2.1 \%$ in 2013 to $3.5 \%$ in 2017 . The average enrolment was at $2.72 \%$. Medical and Health Sciences cluster gradually increased from $2.2 \%$ in 2013 to $3.9 \%$ in 2017, putting the average at 3.12\%. Life and Physical Sciences cluster enrolment increased from 5\% in 2013 to $8.6 \%$ in 2017 , placing the average at $6.89 \%$. Relatively, higher enrolment was recorded in Humanities and Social Sciences, oscillating between 40.3\% lowest in 2017 and $48.1 \%$ highest in 2016. This resulted into an average of $43.4 \%$. Enrolment into Education cluster oscillated between $25.2 \%$ lowest in 2017 and $31.2 \%$ highest in 2014 . This brought the average to $28.03 \%$. Business cluster recorded the highest enrolment of $21 \%$ in 2013 and $10.4 \%$ lowest in 2016. The average enrolment for this cluster was therefore $14.38 \%$ for the period reviewed.

In this connection, one HoD explained:

Some of science and technology Schools like Agriculture and Natural Resources and Life and Physical Sciences were initially domiciled at Chepkoilel Campus which eventually became chartered into a fully-fledged University of Eldoret forcing MU to mount these programmes afresh amidst lack of infrastructure, teaching and learning resources. This probably explains low enrolments recorded. (HoD response during the interview, September, 2019)

From the findings above, most students enrolled into Arts, Social Sciences and Humanities, Education and Business clusters which constituted $85.81 \%$. This meant that only $14.19 \%$ were enrolled into Science and Technology Programmes, missing the government target of $50 \%$ by 35.81 percentage point. In conclusion, there exist systematic imbalances between the number of science-based and arts based students.

The researchers sought to find out participation of students pursuing science and Technology Programmes based on graduation trends. These were analyzed, based on cluster of study areas in Bachelor degree programmes between 2013-2017 academic years. The findings from Egerton University are shown in Figure 4 below: 


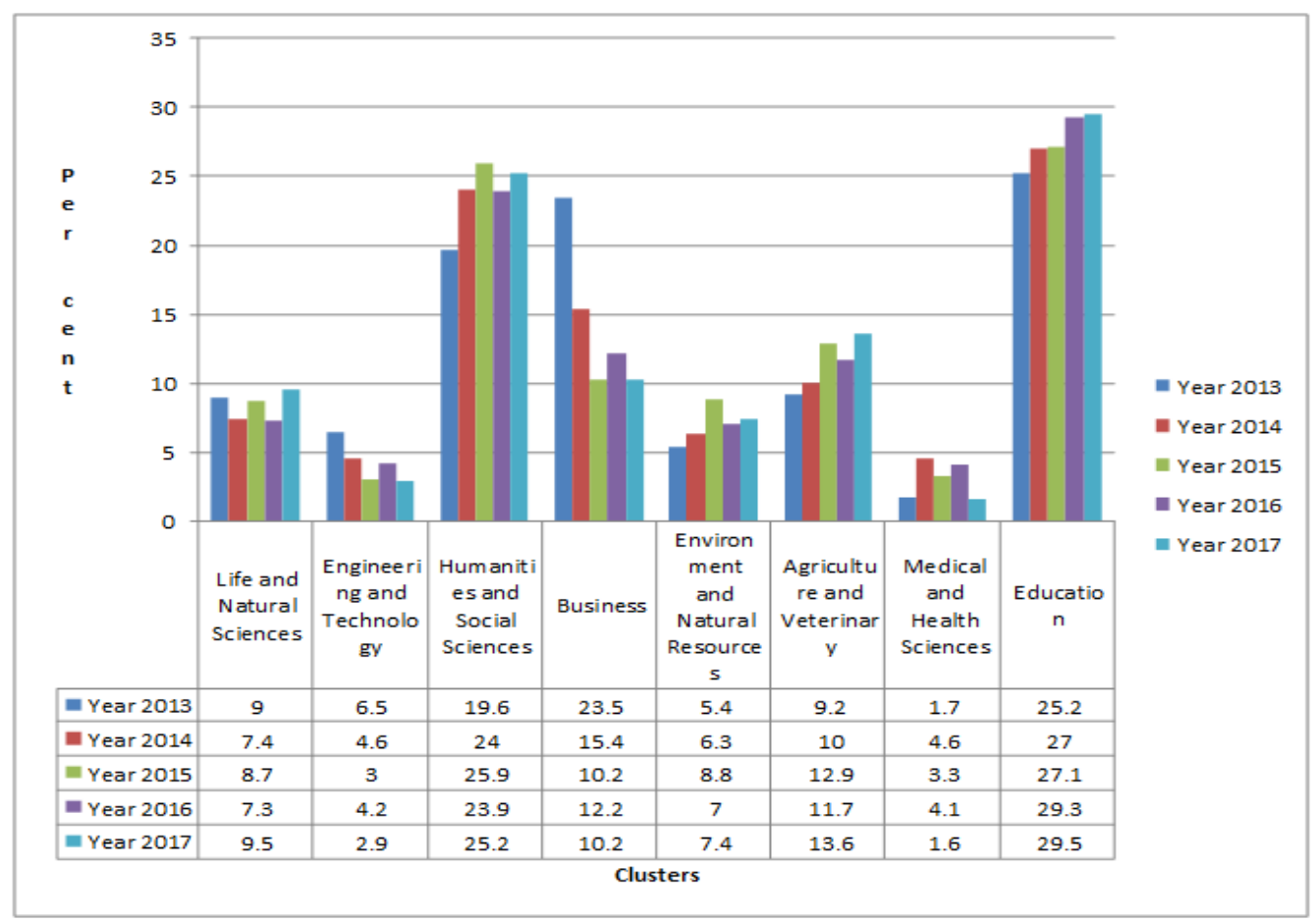

Figure 4. EU Comparative Graduation Trends between 2013-2017 Academic Years for Different Clusters

The Comparative graduation trends appearing in Figure 4 above shows that Medical and Health cluster recorded the lowest number of graduates by recording $1.6 \%$ as lowest in 2017 and $4.6 \%$ as highest in 2014, making the average to be 3.18\%. Engineering and Technology, with the average of $4.0 \%$ was the second with least graduates at $2.9 \%$ in 2017 and highest of $6.5 \%$ in 2013. Environment and Natural Resources was third least represented averaging at $7.2 \%$ with the highest of $8.8 \%$ in 2015 and lowest of 5.4\% in 2013. Life and Natural Sciences came fourth, averaging at $8.36 \%$, with the highest of $9.5 \%$ in 2017 and least of $7.3 \%$ in 2016 . Agriculture and Veterinary Medicine, averaging at $11.77 \%$, was the fifth least represented with $13.6 \%$ as highest in 2017 and least of $9.2 \%$ in 2013 .

The cluster which recorded the highest number of graduates was Education, averaging at $27.87 \%$ with the highest of $29.3 \%$ in 2017 and least of $25.2 \%$ in 2013 . Humanities and Social Sciences were the second highest with the average of $24 \%$. It recorded the highest of $25.9 \%$ in 2015 and lowest of $19.6 \%$ in 2013. Business cluster was third, averaging at $13.3 \%$ with highest number of graduates at $23.5 \%$ in 2013 and lowest of $10.2 \%$ in both 2015 and 2017 . This meant that Education, Humanities and Social Sciences and Business clusters, combined, constituted the lion's share of graduates at $65.17 \%$. By implication, therefore, Egerton University produced only $34.83 \%$ of their graduates in Science and Technology Programmes for the entire period of 2013 to 2017.

Graduation trends for different clusters at Moi University were analyzed and the findings are presented in Figure 5: 


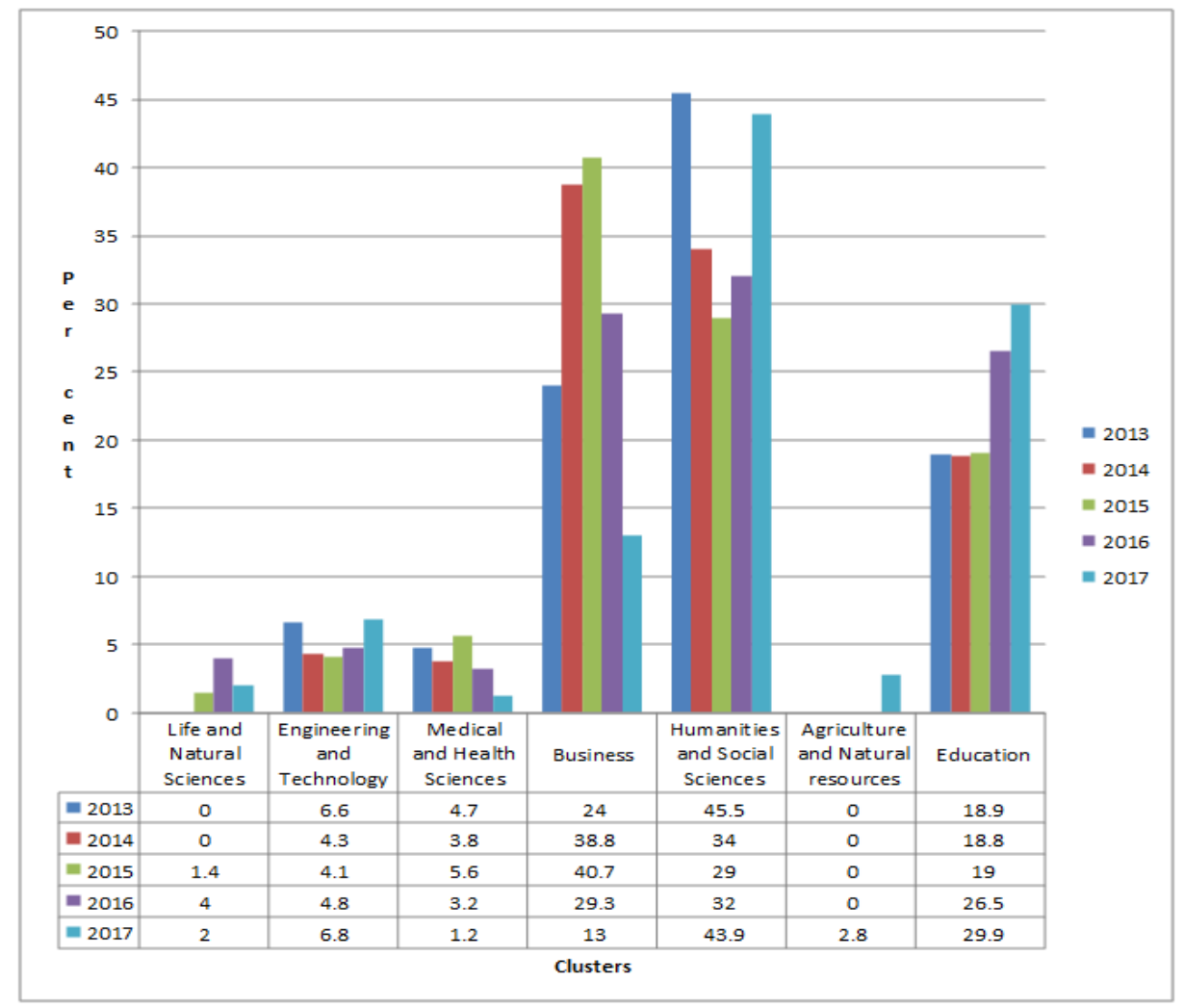

Figure 5. MU Comparative Graduation Trends between 2013-2017 Academic Years for Different Clusters

The Comparative graduation trends appearing in Figure 5 above on average shows that Agriculture and Natural Resources cluster was the least represented with a paltry of $0.4 \%$, only graduating students in 2017 at $2.8 \%$. Life and Natural Sciences was second least represented with an average of $1.58 \%$. The highest in this cluster was $4.0 \%$ in 2016 and the least of $0 \%$ in both 2013 and 2014. Medical and Health Sciences at an average of 3.92\% was third least represented with the highest of $5.6 \%$ in 2015 and lowest of $1.2 \%$ in 2017 . Engineering and Technology, at an average of 5.1\%, was fourth least represented with highest of $6.8 \%$ in 2017 and $4.1 \%$ in 2015. Humanities and Social Sciences cluster was the highest represented with the average of $35.39 \%$, recording the highest of $45.5 \%$ in 2013 and lowest of $29 \%$ in 2015. Business cluster, averaging at $31.32 \%$, was second highest with $40.7 \%$ in 2015 and lowest of $13 \%$ in 2017. Education, averaging at $22.29 \%$, was third recording the highest of $29.9 \%$ in 2017 and lowest of $18.8 \%$ in 2014. This meant that Education, Humanities and Social Sciences and Business clusters combined, constituted the lion's share of graduates at $89 \%$. By implication, therefore, Moi University produced only $11 \%$ of their graduates in Science and Technology Programmes for the entire period of 2013 to 2017. These findings were reinforced by one Registrar (Academic) who argued that:

Low numbers of students graduating in Science and Technology Programmes is largely attributed to the fact that sciences require heavy investments like laboratories, technology and 
libraries which are very inadequate. (Academic Registrar response during the open-ended interview, November, 2019)

Averagely, $23 \%$ of graduates were from Science and Technology Programmes while non-science areas dominated at $77 \%$ during the period reviewed. In summary, Universities are churning out students mostly in Business, Arts and Humanities who constituted $77 \%$ of all students who graduated and a paltry $23 \%$ in Science and Technology Programmes. By implication, too much concentration in non-science was likely to disadvantage some key national development sectors which emphasize science and technology as key requirement for growth and attainment of their aspirations. These observations were supported by OECD (2015) which noted that member countries had three times more Humanities and Social Science graduates than STEM graduates. Moreover, this seemed similar to the findings that in Latin America and the Caribbean, many countries posted lower graduation numbers in Engineering, Manufacturing and Construction clusters (Ferreyra et al (2017).

Data on the total number of Bachelor degree programmes per cluster was collected. The findings are presented in Table 3:

Table 3. The Total Number of Bachelor Degree Programmes per Cluster in the Target Universities

\begin{tabular}{llllll}
\hline Cluster & $\begin{array}{l}\text { Number } \\
\text { programmes }\end{array}$ & of & academic & $\begin{array}{l}\text { Grand } \\
\text { total }\end{array}$ & $\begin{array}{l}\text { Per } \\
\text { cent }\end{array}$ \\
\cline { 2 - 6 } & TUK & MU & EU & & \\
\hline Architecture, Engineering and Technology & 39 & 6 & 5 & 50 & 20.58 \\
Life and Physical sciences & 15 & 12 & 8 & 35 & 14.40 \\
Arts, Humanities and Social sciences & 13 & 50 & 16 & 79 & 32.51 \\
Business & 8 & 3 & 3 & 14 & 5.76 \\
Agriculture, Veterinary and Fisheries & - & 4 & 11 & 15 & 6.18 \\
Medical and Health Sciences & 7 & 8 & 6 & 21 & 8.64 \\
Education & - & 7 & 9 & 16 & 6.59 \\
Environment and Natural Resources & 3 & 2 & 8 & 13 & 5.34 \\
Total & 85 & 92 & 66 & 243 & 100 \\
\hline
\end{tabular}

The total number of Bachelor degree programmes in the Table 2 above indicates that the most popular cluster was Arts, Humanities and Social Sciences. This cluster had 79 programmes out of the total 243 programmes representing 32\%. It was followed by Architecture, Engineering and Technology at (50) 20.58\%, Life and Physical sciences at (35) $14.4 \%$. But the least represented clusters were Environment and Natural Resources at (13) 5.34\%, Business at (14) 5.76\%, Agriculture, Veterinary and Fisheries at (15) $6.18 \%$, Education at (16) 6.59\% and Medical and Health Sciences at (21) 8.64\%.

Therefore, Science and Technology clusters had a total of 134 programmes out of 243, 
representing 55.2\%, while non-science programmes were 109 representing $44.8 \%$. Hence, Public Universities in Kenya have attempted to prioritize programmes in science and technology clusters. In this regard, one HoD explained:

There has been an increase in the number of Engineering Programmes. We largely offered Agriculture Engineering Programme in the faculty of Agriculture but in the recent past, we have significantly expanded this programme into a full-fledged Faculty of Engineering and Technology now offering six Bachelor's degree programmes. (HoD response during open-ended interview, September, 2019)

Regarding the aspect academic programmes on offer, one Academic Registrar pointed out:

The programmes on offer are largely determined by a number of factors like the nature of the institution's establishment, market forces, and controls by Commission for University Education and other professional bodies, availability and adequacy of space, facilities, and teaching staff among others. (Academic Registrars' response to an open-ended interview, November 2019)

Another Academic Registrar stated:

Due to the fact that sciences require heavy investment in terms of laboratories and technologies, Universities previously focusing on science and technology are moving towards more generic applied sciences areas. (Academic Registrar's response to an open-ended interview in November 2019)

A lecturer lamented:

We offer Bachelor of Engineering in Civil Engineering, Bachelor of Technology in Civil Engineering Technology and Bachelor of Philosophy in Technology Civil Engineering. Similarly, we offer Bachelor of Engineering in Mechanical Engineering, Bachelor of Technology in Mechanical Engineering and Bachelor of Philosophy in Technology Mechanical Engineering. Definitely, market forces determine the programmes on offer. (Lecturer response to an open-ended interview, November 2019)

Another lecturer pointed out:

We have split Electrical Engineering into Electrical and Electronic Engineering, Electrical and Computer Engineering and Electrical and Telecommunication Engineering. Market trends largely influences this concept. (Lecturer response to an open-ended interview, November 2019)

These sentiments allude to the fact that marketing trajectory has forced Universities to offer programmes perceived to have market for attracting students. However, they are limited due to lack of infrastructure, teaching, and learning resources. Consequently, "programmatic isomorphism" -a concept where Universities gradually shade off their technical orientation in favour of Arts and Humanities degree programmes has ensued. A second and apparent contradiction is the tendency of programmes duplication within same institution and "course splintering”. In summary, although many Science and Technology Programmes are on offer, 
the emerging picture if unchecked will eventually reverse the trend and programmes which are critical to realization of the development agenda and vision 2030 would, therefore, not be adequately offered in the long run.

These observations were supported by Sam-Amoah et al, (2016) \& Owusu-Ansah (2013) in Ghana who documented that there was poor enforcement of policy targets for Science and Technology Programmes by the higher education institutions where science-based had expanded the number of Arts and Humanities Programmes offered. Moreover, Valeta et al. (2016) in Malawi found out that several new programmes with a lot of specialization had been established and concluded that this practice makes the over specialized graduates to lack versatility.

\section{Conclusion}

The study concludes that contrary to the Government of Kenya policy on enrolment ratios for programmes in science and technology and non-science, the target was missed. Also, the distribution of students in academic programmes was not aligned to the stated policy. Therefore, the government was not producing enough graduates to realize her aspiration of using science and technology as a way of underpinning economic development.

\section{Recommendations}

The study recommends that Universities should rationalize and balance enrolment into University programmes so that they are clearly aligned to the development needs of the country. The percentage of academic programmes which have greatest bearing on the development agenda need to be directly proportional to the percentage of its goals. Consequently, this should hinge on successful implementation of government's admission policies.

\section{References}

Africa Union Commission. (2014). Agenda 2063: The Africa We Want. Addis Ababa: Africa Union Commission.

African Capacity Building Foundation. (2016). Africa Union Agenda 2063: African Critical Technical Skills: Key Dimensions Needed for the First 10 Years of Agenda 2063. Harare: African Capacity Building Foundation. ISBN/ISSN 9781779370631 URL. Retrieved from http://www.acbf-pack.org

Atuahene, F., \& Owusu-Ansah, A. (2013). A Descriptive Assessment of Higher Education Access, Participation, Equity and Disparity in Ghana. Sage Open, 3(3). https://doi.org/10.1177/2158244013497725

Bagde, S., Epple, D., \& Taylor, L. (2016). Does Affirmative Action Work? Caste, Gender, 
College Quality, and Academic Success in India. American Economic Review, 106(6), 1495-1521. https://doi.org/10.1257/aer.20140783

Blom, A., Raza, R., Kiamba, C., Bayusuf, H., \& Adil, M. (2016). Expanding Tertiary Education for Well-paid Jobs: Competitiveness and Shared Prosperity in Kenya. Washing DC: World Bank. https://doi.org/10.1596/978-1-4648-0848-7

Cohen et al. (2007). Research Methods in Education (6th ed.). London: Taylor and Francis Group. https://doi.org/10.4324/9780203029053

Commission for University Education. (2016). University Statistics in Kenya. Nairobi: Commission for University Education.

Federation of India Chambers of Commerce and Industry. (2014). Higher Education in India: Moving Towards Global Relevance and Competitiveness. New Delhi: Federation of India Chambers of Commerce and Industry.

Ferreyra, M. M., Avitabile, C., Alvarez, B. J., Paz, H. F., \& Urzua, S. (2017). At a Crossroads: Higher Education in Latin America and the Caribbean. Washington DC: World Bank. https://doi.org/10.1596/978-1-4648-1014-5

Filippetti, A., \& Savona, M. (2017). University-Industry Linkages and Academic Engagements: Individual Behaviors and Firms' Barriers. Introduction to Special Section. The Journal of Technology Transfer. https://doi.org/10.1007/s 10961-017-9576-x

Garwe, C. E. (2015). Trends in Student Enrolments in Agricultural Degree Programme in Zimbabwe. Global Journal of Educational Studies, 1(1). 62-77. https://doi.org10.5296/gjes.v1il.7615

Karimi, K. F. (2015). Academic Programmes in Universities in East Africa: A catalyst to Development. International Journal of Higher Education, 4(3), 140-155. https://doi.org/10.5430/ijhe.v4n3p140

Koketso, P. L. (2015). STEM Education in Botswana: Understanding the Gender Disparity in Enrolment and Graduation in Post- Secondary Education. Montreal, Quebec: Concordia University.

Kombo, D. K., \& Tromp, D. L. (2006). Proposal and Thesis Writing: An Introduction. Nairobi: Paulines Publications Africa.

KUCCPS. (2014, December 15th). Kenya Universities and Colleges Central Placement $\begin{array}{lllll}\text { Services. } & \text { Retrieved } & 15 & \text { December, } & 2016\end{array}$ www.kuccps.net/sites/default/placement $\% 20 \%$ policyAug-pdf

Misaro, J., Jonyo, O. F., \& Kariuki, K. D. (2013). A Review of the Impact of Massification on the Quality of Higher Education in Kenya. Research in Organizational Psychology and Educational Studies, 2(4), 139-149.

Mpehongwa, G. (2014). Career Choices of University Students in Tanzania and their Implications for Vision 2025. International Journal of Humanities and Social Science, 
4(5), 260-266.

Muema, E., \& Lavery, R. M. (2018). Redefining Quality in Higher Education: The Concept of Juakalization. Sino-Us English Teaching, 15(9), 415-428. https://doi.org/10.17265/1539-8072/2018.09.001

OECD. (2015). How is the global talent pool changing (2013, 2030)? Education Indicators in Focu 31. Paris: OECD publishing. https://doi.org/10.1787/5js331f9jk41-en

Patton, M. Q. (2002). Qualitative Research and Evaluation Methods (3rd ed.). California: SAGE Publications. Thousand Oaks.

Republic of Kenya. (1974). Development Plan, 1974-1978. Nairobi: Government Printer.

Republic of Kenya. (1976). Report on the National Committee on Educational Objectives and Policies. Nairobi: Government Printer.

Republic of Kenya. (1979). Development Plan, 1979-1983. Nairobi: Government Printer.

Republic of Kenya. (1981). Second University in Kenya: Report of the Presidential Working Party. Nairobi: Government Printer.

Republic of Kenya. (2005). Kenya Education Sector Support Programme (KESSP) 2005-2010. Nairobi: Ministry of Education, Science and Technology.

Republic of Kenya. (2006). Transforming of Higher Education and Training in Kenya to Secure Kenya's Development in the Knowledge Economy, Report of the Public Universities Inspection Board. Nairobi: Government printer.

Sader, B. S., \& Gabela, N. P. (2017). Spatialities of Widening Participation: Narratives of First Year Students Receiving Financial Aid. South African Journal of Higher Education, 31(1), 227-242. https://doi.org/10.20853/31-1-1056

Sam-Amoah, L. K., Yawson, D. O., Agyeifrimpong, K., \& Abole, E. (2016). Status and Challenges of the Higher Agricultural Education Sector in Ghana. African Journal of Rural Development, 1(2), 159-169. https://doi.org/10.22004/ag.econ.263566

Too, J., Njeru, M., \& Adoyo, C. (2018). Towards Becoming an Industrialized Middle-Income Country: Recasting the Focus. Nairobi: Commission for University Education.

UNESCO. (2010). National Education Support Strategy (UNESS) for the Republic of Kenya 2010-2011. Nairobi: UNESCO.

Valeta, J., Sefasi, A., \& Kalizang'oma, R. (2016). Status of Higher Education, Science and Technology in Malawi: A Focus on Agricultural Higher Education. African Journal of Rural Development, 1(2), 179-192. https://doi.org/10.22004/ag.econ.263568

World Bank. (2014). Kenya's Education Achievement and Challenges. Washington, DC: World Bank.

Yingyi, M., \& Liu, Y. (2017). Entry and Degree Attainment in STEM: The Intersection of 
Gender and Race/ Ethinicity. Social Sciences, 6(89), 1-17. https://doi.org/10.3390/socsci6030089

\section{Copyrights}

Copyright for this article is retained by the author(s), with first publication rights granted to the journal.

This is an open-access article distributed under the terms and conditions of the Creative Commons Attribution license (http://creativecommons.org/licenses/by/4.0/) 